\title{
Chemical tools selectively target components of the PKA system
}

\author{
Daniela Bertinetti ${ }^{\dagger 1}$, Sonja Schweinsberg ${ }^{\dagger 1}$, Susanne E Hanke1, \\ Frank Schwede ${ }^{2}$, Oliver Bertinetti ${ }^{1}$, Stephan Drewianka ${ }^{3}$, Hans- \\ Gottfried Genieser ${ }^{2}$ and Friedrich W Herberg*1
}

\author{
Address: ${ }^{1}$ Department of Biochemistry, University of Kassel, Heinrich-Plett-Str. 40, 34132 Kassel, Germany, ${ }^{2}$ Biolog Life Science Institute, \\ Flughafendamm 9a, P.O. Box 107125, Bremen, Germany and ${ }^{3}$ Biaffin GmbH \& Co KG, Heinrich-Plett-Str. 40, 34132 Kassel, Germany \\ Email: Daniela Bertinetti - d.bertinetti@uni-kassel.de; Sonja Schweinsberg - sonja.schweinsberg@uni-kassel.de; \\ Susanne E Hanke - s.hanke@uni-kassel.de; Frank Schwede - fs@biolog.de; Oliver Bertinetti - bertinetti@uni-kassel.de; \\ Stephan Drewianka - drewianka@biaffin.de; Hans-Gottfried Genieser - hgg@biolog.de; Friedrich W Herberg* - herberg@uni-kassel.de \\ * Corresponding author †Equal contributors
}

Published: 12 February 2009

BMC Chemical Biology 2009, 9:3 doi:10.1 186/1472-6769-9-3
Received: 10 September 2008

Accepted: 12 February 2009

This article is available from: http://www.biomedcentral.com/I472-6769/9/3

(C) 2009 Bertinetti et al; licensee BioMed Central Ltd.

This is an Open Access article distributed under the terms of the Creative Commons Attribution License (http://creativecommons.org/licenses/by/2.0), which permits unrestricted use, distribution, and reproduction in any medium, provided the original work is properly cited.

\begin{abstract}
Background: In the eukaryotic cell the cAMP-dependent protein kinase (PKA) is a key enzyme in signal transduction and represents the main target of the second messenger cAMP. Here we describe the design, synthesis and characterisation of specifically tailored CAMP analogs which can be utilised as a tool for affinity enrichment and purification as well as for proteomics based analyses of cAMP binding proteins.
\end{abstract}

Results: Two sets of chemical binders were developed based on the phosphorothioate derivatives of cAMP, Sp-cAMPS and Rp-cAMPS acting as CAMP-agonists and -antagonists, respectively. These compounds were tested via direct surface plasmon resonance (SPR) analyses for their binding properties to PKA R-subunits and holoenzyme. Furthermore, these analogs were used in an affinity purification approach to analyse their binding and elution properties for the enrichment and improvement of cAMP binding proteins exemplified by the PKA R-subunits. As determined by SPR, all tested Sp-analogs provide valuable tools for affinity chromatography. However, Sp-8-AEAcAMPS displayed (i) superior enrichment properties while maintaining low unspecific binding to other proteins in crude cell lysates, (ii) allowing mild elution conditions and (iii) providing the capability to efficiently purify all four isoforms of active PKA R-subunit in milligram quantities within $8 \mathrm{~h}$. In a chemical proteomics approach both sets of binders, Rp- and Sp-cAMPS derivatives, can be employed. Whereas Sp-8-AEA-cAMPS preferentially binds free R-subunit, Rp-AHDAA-cAMPS, displaying antagonist properties, not only binds to the free PKA R-subunits but also to the intact PKA holoenzyme both from recombinant and endogenous sources.

Conclusion: In summary, all tested CAMP analogs were useful for their respective application as an affinity reagent which can enhance purification of CAMP binding proteins. Sp-8-AEA-cAMPS was considered the most efficient analog since Sp-8-AHA-cAMPS and Sp-2-AHA-cAMPS, demonstrated incomplete elution from the matrix, as well as retaining notable amounts of bound protein contaminants. Furthermore it could be demonstrated that an affinity resin based on Rp-8-AHDAAcAMPS provides a valuable tool for chemical proteomics approaches. 


\section{Background}

The cAMP-dependent protein kinase (PKA) is a key regulator protein in eukaryotic signal transduction and is involved in several cellular processes during growth and development. Via phosphorylation of its substrate proteins PKA controls metabolic processes, cAMP mediated gene expression, cell differentiation and/or apoptosis [1]. The enzymatic activity of the PKA catalytic (C) subunit is controlled by a set of four different regulatory (R) subunit isoforms, i.e. type I and type II, both with two isoforms ( $\alpha$ and $\beta$ ) each. Thus, in its inactive state PKA forms a heterotetrameric holoenzyme complex $\left(\mathrm{R}_{2} \mathrm{C}_{2}\right)$, containing an R-subunit dimer and two C-subunit monomers. The PKA holoenzyme is activated upon cooperative binding of four molecules of the second messenger cAMP to the R-subunits, thus releasing the now active C-subunits [2]. The expression pattern of single PKA isoforms as well as the isoform specific composition of the holoenzyme and tissue specific distribution of PKA isoforms allows a tight regulation of the catalytic activity of PKA. In turn, PKA provides an important model system for kinases, allowing investigation of the molecular mechanisms of kinase function as well as the development of tools for diagnostic purposes which in turn enables their use as biomarkers [3].

Historically, purification of PKA holoenzyme from biological material was performed via anion exchange chromatography (DEAE, [4]); later, a second step based on affinity purification utilising cAMP resins was added $[5,6]$. However, most strategies so far resulted in either partly degraded or insoluble protein with limited yield. Therefore we set out to design novel cAMP affinity matrices for simple and rapid purification of cAMP binding proteins. These resins should provide a chemical tool that targets proteins containing the conserved cAMP binding domains, specifically PKA R-subunits while fulfilling the following criteria required for efficient affinity binders:

\section{Purify high quantities of selected protein of interest;}

\section{2. yield functionally active protein;}

3. provide a purification procedure with mild but efficient elution conditions while retaining high yields of protein;

4. obtain nucleotide-free proteins which can easily be used for further interaction studies and biochemical assays;

5. provide an easy-to-use procedure applicable in chemical proteomics.

In addition to cAMP's role as a general activator of all holoenzyme isoforms, with PKA representing the main intracellular effector of cAMP, there are still other targets of cAMP like nucleotide-gated ion channels [7], cAMP degrading phosphodiesterases [8] or Epac, the cAMP-regulated guanine nucleotide-exchange factor for Rap 1 and 2 [9], all containing one or more highly conserved cyclic nucleotide binding (CNB) domains [10].

PKA R-subunits and specific components of the cAMP signalling network can be precisely targeted from complex protein mixtures using highly specific CAMP analogs covalently coupled to agarose beads. Generally, two groups of chemical tools are used for the affinity purification of functional complexes: agonist and antagonist binders (Fig. 1A). Agonist binders are synthetic cyclic nucleotides which bind the R-subunits that are complexed with interaction partners (e.g. AKAPs), however, these agonists cause the PKA holoenzyme to dissociate. Antagonist binders, interacting preferentially with the intact, non dissociated PKA holoenzyme, can be utilised to identify interaction partners that bind to the entire complex $\left(\mathrm{R}_{2} \mathrm{C}_{2}\right)$, including proteins interacting with the C-subunits.

In the present study several cyclic nucleotide analogs were synthesised and optimised for their binding properties to the respective components of the PKA system using an iterative approach based on direct SPR binding studies. Subsequently, these cAMP analogs were coupled to a solid support and tested for binding and elution in a one step purification procedure probing all four recombinantly expressed R-subunit isoforms. Furthermore, we tested optimised cyclic nucleotides analogs for their application in a chemical proteomics approach addressing either the R-subunits or the intact PKA holoenzyme complex along with physiological interaction partners derived from animal tissue.

\section{Results}

In previous studies, hundreds of cyclic nucleotides were developed and characterised regarding their binding ability to proteins containing cyclic nucleotide binding (CNB) domains [11-14].

\section{Improved CAMP analogs as novel tools for PKA R-subunit purification}

For our developments we used optimised binders based on Sp-cAMPS (Fig. 1A left panel, 1B), a cAMP analog where the axial exocyclic oxygen atom of the cyclic phosphate is replaced by a sulphur atom, resulting in an approximately 10 -fold reduced affinity towards the R-subunit when compared to cAMP alone [15-17]. In order to couple Sp-cAMPS to a solid phase, analogs with different spacers in positions 2 or 8 of the adenine base (Sp-8-AEAcAMPS， Sp-8-AHA-CAMPS， Sp-2-AHA-cAMPS， Fig. 1B) were designed and synthesised. Two complementary strat- 


\section{A}
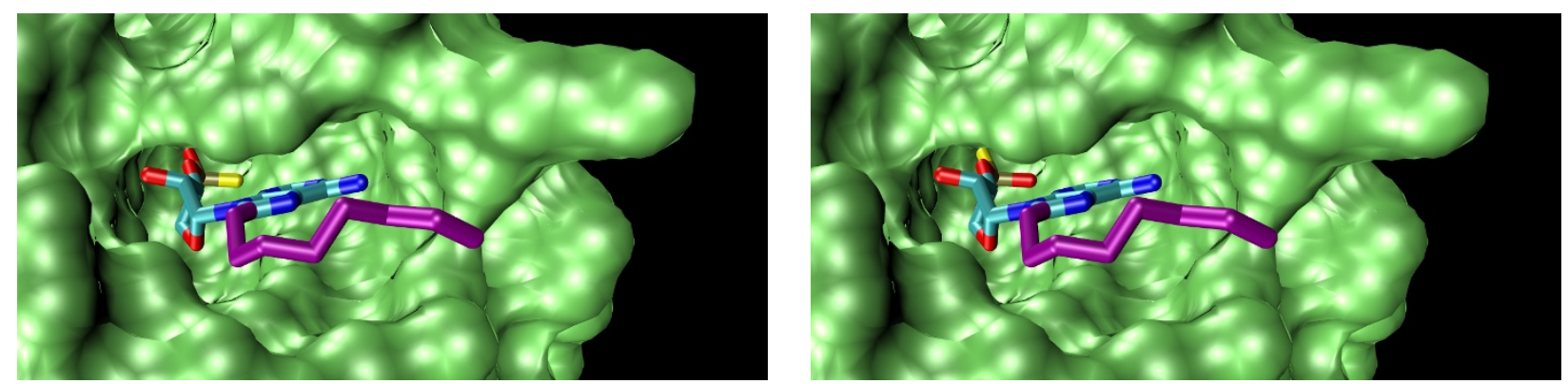

B

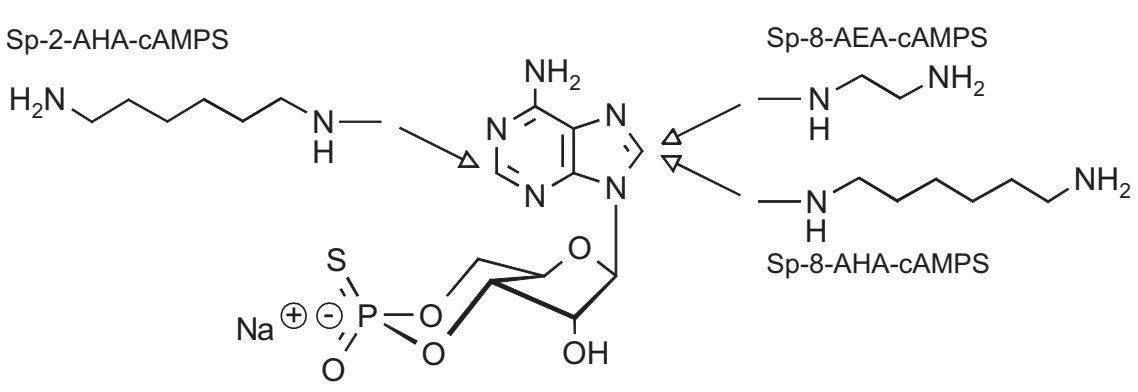

C

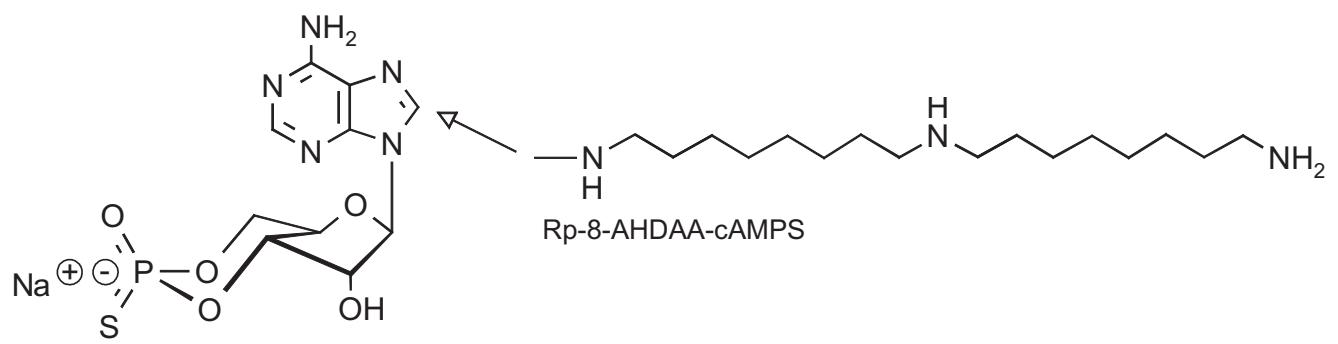

Figure I

Chemical structures of cyclic nucleotides. (A) Model of the bovine Rl $\alpha$ subunit (PDB-ID IRGS) with bound agonist (Sp8-AHA-cAMPS, left) and antagonist (Rp-8-AHA-cAMPS, right). The figure was created using standard settings in VMD I.8.4 [58]. Chemical structures of Sp-cAMPS (B) and Rp-cAMPS (C) analogs. Arrows indicate positions of attached linkers.

egies were combined for the characterisation of improved binders for PKA R-subunit purification. In initial kinetic studies, surface plasmon resonance (SPR) was employed and selected CAMP analogs were immobilised on a sensor chip and the association and dissociation patterns of all four R-subunit isoforms were analysed in detail. In an additional approach, these cAMP analogs were coupled to agarose beads and their ability for affinity purification of R-subunits was studied via pull down experiments. In both sets of experiments, 8-AHA-CAMP and 8-AEA-cAMP were used as controls, since they represent conventional cAMP analogs which have been commonly applied for purification of PKA R-subunits or for interaction studies in previous reports $[6,12,18-29]$.

\section{SPR binding studies}

8-AEA-CAMP, 8-AHA-cAMP, Sp-8-AEA-cAMPS, Sp-8-AHAcAMPS and Sp-2-AHA-cAMPS were covalently coupled to a sensor surface using NHS/EDC chemistry and the association and dissociation patterns of the four different Rsubunit isoforms $(\mathrm{RI} \alpha, \mathrm{RI} \beta, \mathrm{RII} \alpha, \mathrm{RII} \beta)$ were analysed using a Biacore 2000 instrument (Fig. 2). All four R-subunit isoforms showed fast association behaviour when binding to the immobilised cAMP analogs. No notable dissociation could be detected when switching the instrument to buffer, thus indicating a stable interaction between the R-subunit and the immobilised cAMP analogs (Fig. 2F). When adding cGMP ( $3 \mathrm{mM}$ ) during the dissociation phase the dissociation behaviour from an 


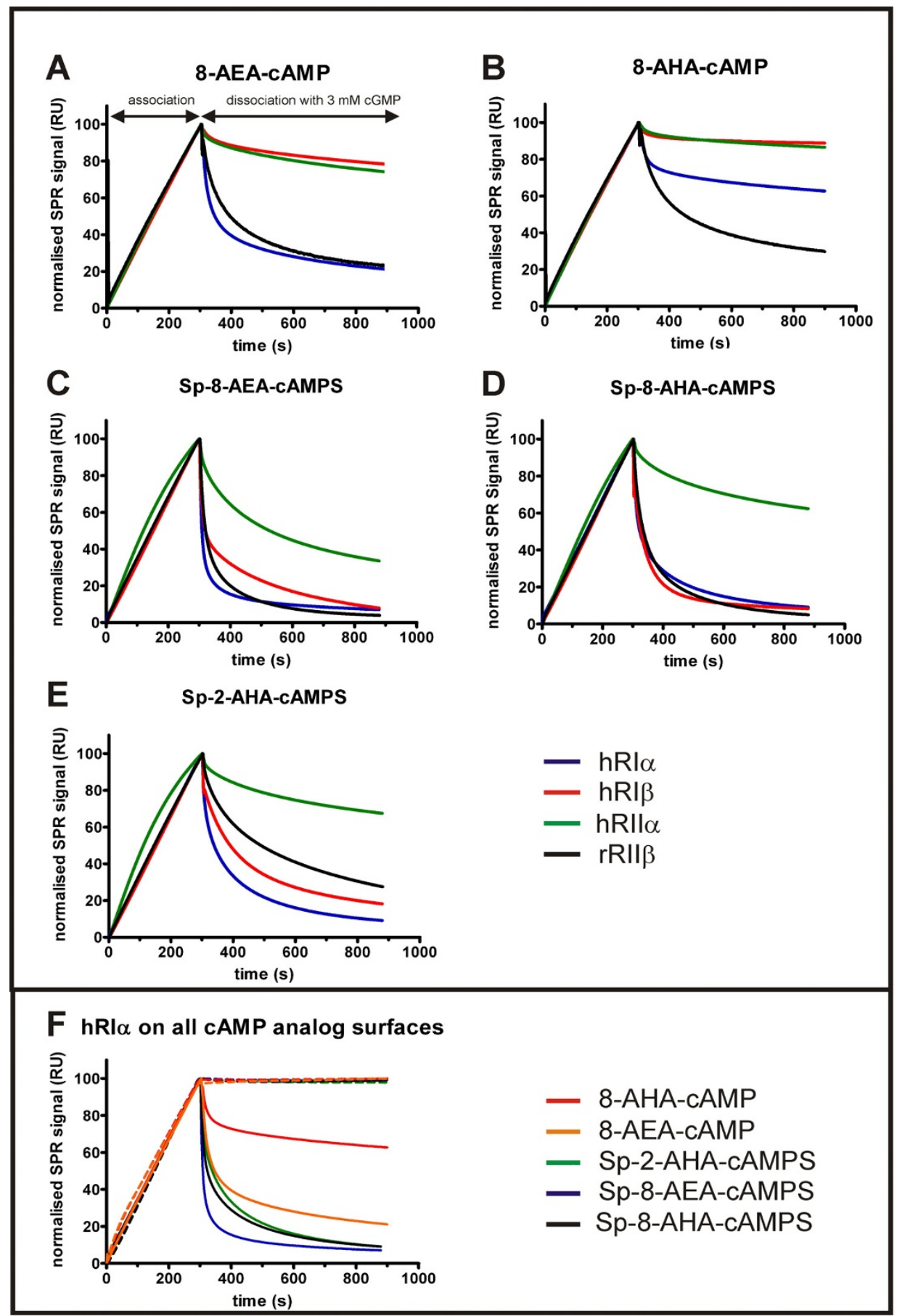

Figure 2

Interaction of R-subunit isoforms with immobilised cAMP analogs investigated by SPR. Binding of all four R-subunit isoforms (100 nM) to immobilised 8-AEA-cAMP (A), 8-AHA-cAMP (B), Sp-8-AEA-cAMPS (C) and Sp-8-AHA-cAMPS (D) Sp-2-AHA-cAMPS (E) using a flow rate of $10 \mu \mathrm{L} / \mathrm{min}$ in buffer A containing $0.005 \% \mathrm{P} 20$. Association and dissociation of $\mathrm{hRl} \alpha$ (blue), hRI $\beta$ (red), hRIl $\alpha$ (green) and rRII $\beta$ (black) were monitored for 5 and 10 min, respectively. The dissociation was monitored in the presence of $3 \mathrm{mM}$ cGMP. $(\mathrm{F})$ hRl $\alpha$ binding to five different cAMP analogs. $100 \mathrm{nM}$ hRl $\alpha$ was injected to immobilised 8-AHA-cAMP (red), 8-AEA-cAMP (orange), Sp-2-AHA-cAMPS (green), Sp-8-AEA-cAMPS (blue) and Sp-8-AHA-cAMPS (black). Dissociation was initiated either by buffer A containing $0.005 \%$ P20 (dotted lines) or by $3 \mathrm{mM}$ cGMP in the same buffer (solid lines). Experimental setup was performed as described above. 
immobilised cyclic nucleotide analog was affected by (i) the exchange of the exocyclic oxygen to a sulphur in the immobilised cAMP analog, (ii) the chosen linker of the cAMP analog and (iii) the R-subunit isoform. In general, dissociation in the presence of cGMP was slower for conventional CAMP analogs compared to the newly designed Sp-cAMPS analogs. When comparing dissociation from all Sp-cAMPS analogs, a slower dissociation was observed from the 2-substituted analog (Fig. 2E) than from the 8substituted analog (Fig. 2C, D). Among the R-subunit isoforms, RIIa displayed the slowest dissociation from all five analog surfaces tested.

Generally, fast binding to the affinity matrix as well as rapid and complete dissociation under elution conditions are preferred for purification, without the dissociation of protein from the affinity matrix under washing conditions. From the observed elution patterns, Sp-8-AEAcAMPS was considered the best candidate for efficient elution of hRI $\alpha$ (Fig. 2C, F), especially when compared to 8AHA-CAMP and 8-AEA-CAMP which conventionally have been employed (Fig. 2A, B) [18,27-29]. Panels A and B (Fig. 2) clearly demonstrate that the RI $\beta$ and RII $\alpha$ dissociate rather slow from the non Sp-cAMPS analogs, even in the presence of cGMP. In general, for the R-subunit isoforms RI $\beta$, RII $\alpha$ and RII $\beta$, the dissociation with cGMP is fast and almost identical for the 8-substituted cAMPS analogs.

As a consequence of the high surface ligand density the association and dissociation patterns of the R-subunits to the immobilised cAMP analogs were severely affected by mass transfer limitations. These limitations are due to depletion of the analyte (here the R-subunits) being in close proximity to the sensor surface during association, thus prohibiting the quantitative analyses of association and dissociation kinetics. Furthermore, rebinding effects in the dissociation phase are intensified by the presence of four cAMP binding sites per R-subunit dimer [30-32]. Still, the high surface density of cAMP analogs on the sen- sor surface very well represents the situation that is occurring on the agarose beads during binding and elution.

\section{Purification of the R-subunit isoforms using Sp-cAMPS agaroses}

The analogs tested in SPR (8-AEA-CAMP, 8-AHA-cAMP, Sp-8-AEA-cAMPS, Sp-8-AHA-cAMPS and Sp-2-AHAcAMPS) were coupled to agarose beads using NHS chemistry (Fig. 3). Bacterial cell lysate containing overexpressed RI $\alpha$ was incubated with each analog coupled to agarose (a representative purification procedure with Sp-8-AEAcAMPS is shown in Fig. 4A). After several washing steps were performed, no notable dissociation of the RI $\alpha$ subunit from the agarose was detected. Elution of the protein with $10 \mathrm{mM}$ cGMP resulted in a protein fraction containing highly pure and active R-subunit as determined by SDS-PAGE and spectrophotometric activity assay [33], yielding $12 \mathrm{mg}$ protein per approximately $400 \mu \mathrm{L}$ of agarose slurry. Only little additional protein could be eluted subsequently with CAMP, still leaving some protein on the agarose beads (Fig. 4A).

cGMP elution from the other two agaroses (Sp-8-AHAcAMPS and Sp-2-AHA-cAMPS) resulted in half the amount of purified PKA R-subunit (7.2 mg protein per approximately $400 \mu \mathrm{L}$ of agarose slurry, Fig. 4B) when compared to the yield from the Sp-8-AEA-cAMPS agarose. Furthermore, hRI $\alpha$ could only be partially eluted from the Sp-8-AHA-cAMPS agarose with $10 \mathrm{mM}$ cAMP, while leaving a significant amount of protein on the beads, thus indicating that RI $\alpha$ binds too tight to this analog and therefore can not be used for this affinity purification procedure. Additionally, both the Sp-2-AHA-cAMPS and Sp8-AHA-cAMPS agarose showed a $25 \mathrm{kDa}$ protein coeluted with cGMP, it was identified by mass spectrometry (MS) as E. coli Chloramphenicol Acetyltransferase which is abundant in the BL21 (DE3) Codon Plus RIL strain (Fig. 4B).

Thus, from the three affinity resins tested, only Sp-8-AEAcAMPS fulfils and exceeds all necessary requirements for

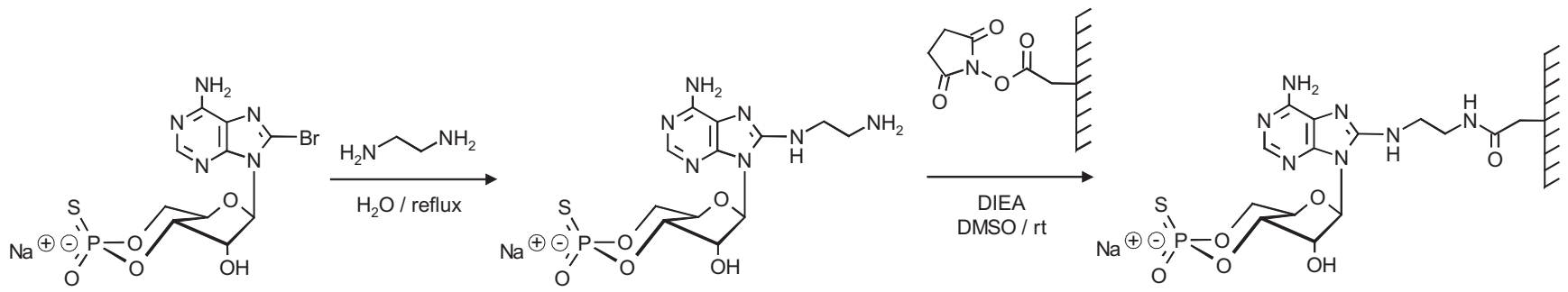

\section{Figure 3}

Coupling of cyclic nucleotides to a solid support. Representative scheme showing synthesis and coupling of Sp-8-AEAcAMPS to NHS-activated agarose beads (Affi-Gel ${ }^{\circledR}$ I0, BIO-RAD). For details of synthesis and coupling see Methods section. 


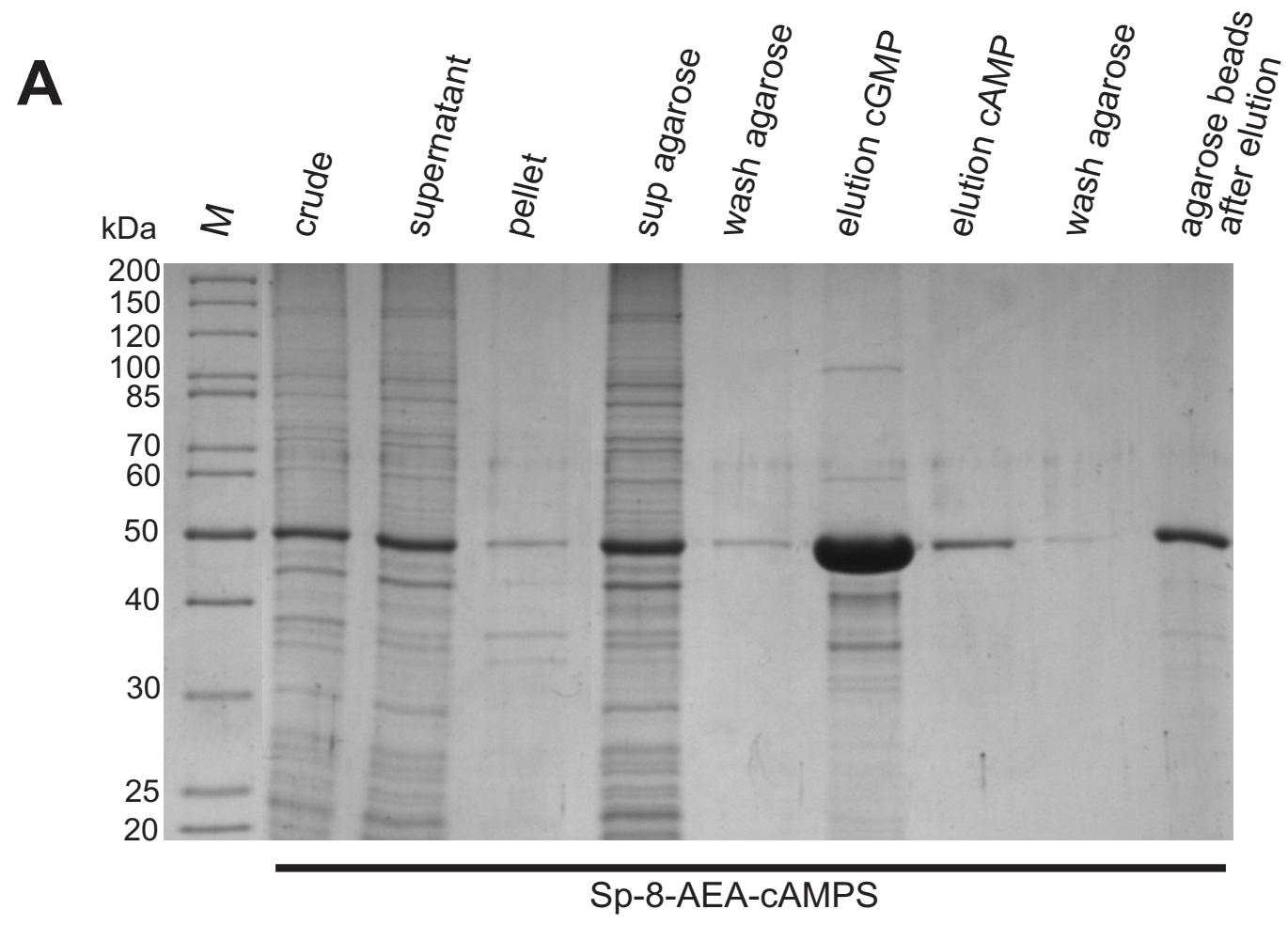

B

Figure 4 (see legend on next page)

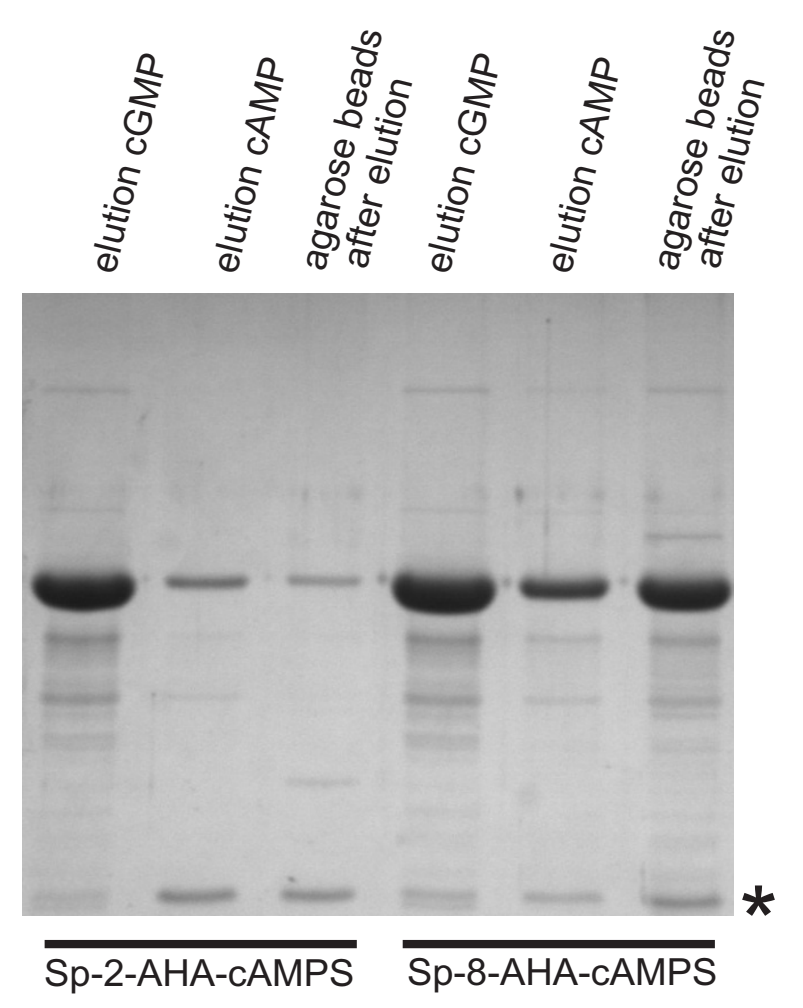


Figure 4 (see previous page)

Purification of hRI $\alpha$ subunit with different Sp-cAMPS analog agaroses analysed by SDS-PAGE. (A) crude: total cell extract of $E$. coli BL2I DE3 Codonplus RIL with overexpressed hRl $\alpha$ at $52 \mathrm{kDa}$; supernatant: soluble fraction of bacterial lysate after French Press and centrifugation; pellet: insoluble fraction; sup agarose: unbound protein after incubation with Sp-8-AEACAMPS agarose; wash agarose: aliquot after 6 washing steps with buffer B; elution CGMP and elution cAMP: elution with 10 mM cGMP and subsequently with 10 mM cAMP, respectively; wash agarose: aliquot after 6 washing steps with buffer B; agarose beads after elution: remaining protein on the agarose beads after the two elution and washing steps. M: molecular weight marker (Page-Ruler Unstained Protein Ladder, Fermentas). (B) Total cell extract of E. coli BL2I DE3 Codonplus RIL with overexpressed hRl $\alpha$ was incubated with Sp-2-AHA-cAMPS and Sp-8-AHA-cAMPS, respectively, and eluted with cGMP (I0 mM, lane I and 4) and subsequently with cAMP (I0 mM, lane 2 and 5). Only a low amount of protein was left on Sp-2-AHA-cAMPS agarose after elution with cAMP (lane 3), whereas significant amounts of R-subunit remained on Sp-8-AHA-cAMPS agarose (lane 6). Asterisk indicates Chloramphenicol Acetyltransferase from E. coli BL2I (DE3) Codon Plus RIL as identified by MS.

improved affinity purification when compared to conventional 8-AEA- or 8-AHA-cAMP agarose chromatography [18] and thus appears to be the best option for isolating large quantities of pure and active RI $\alpha$.

\section{Comparison of conventional agaroses 8-AHA-cAMP and 8- AEA-cAMP with SP-8-AEA-cAMPS}

The Sp-8-AEA-cAMPS resin as well as the conventional agaroses 8-AHA-cAMP and 8-AEA-cAMP were all tested via small scale purification with all four R-subunit isoforms, namely RI $\alpha$, RI $\beta$, RII $\alpha$ and RII $\beta$. The protein yields eluted first with cGMP and then subsequently in a second elution step with CAMP are displayed in Fig. 5. As a control the cAMP elution was performed according to Diller et al. [18]. All R-subunit isoforms were obtained in a pure and active form as determined by a spectrophotometric assay [33]. Since the highest overall yield of the respective Rsubunit was obtained using Sp-8-AEA-cAMPS agarose, this amount was set as the $100 \%$ reference point (Fig. 5A). Interestingly, mild elution of RIa subunit with cGMP from the Sp-8-AEA-cAMPS agarose is nine times more efficient than the cGMP elution from the 8-AEA-cAMP agarose. Furthermore, a fourfold higher yield was obtained from the cGMP elution only using the Sp-cAMPS agarose than from combining both elution steps (cGMP and CAMP) employing 8-AEA-cAMP together. Purification of RI $\alpha$ with 8-AHA-cAMP agarose was even less efficient than using 8-AEA-CAMP (Fig. 5B). Still, the amount of RI $\beta$, RII $\alpha$ and RII $\beta$ isoforms eluted from our newly designed Sp-8AEA-CAMPS agarose was a minimum of $40 \%$ greater than from the conventional agaroses.

In a further experiment all four R-subunit isoforms were purified with the Sp-8-AEA-cAMPS agarose (data not shown). The purification of RI $\alpha$ and RII $\alpha$ isoforms resulted in $12 \mathrm{mg}$ protein per liter expression media. For $\mathrm{RI} \beta$ and RII $\beta$ isoforms $5 \mathrm{mg}$ and $3 \mathrm{mg}$ protein were purified respectively. All affinity purified proteins were verified by MS (data not shown). The entire purification procedure of each R-subunit isoform was completed within $8 \mathrm{~h}$.

\section{Binding of the PKA holoenzyme complex to agonist and antagonist}

Based on the purification strategy described above, novel cAMP derivatives with antagonist properties were designed to analyse the PKA holoenzyme $\left(\mathrm{R}_{2} \mathrm{C}_{2}\right)$ complex and target physiological interaction partners via a chemical proteomics approach. Only cAMP analogs derived from the lead structure Rp-cAMPS (replacement of the equatorial exocyclic oxygen of the cyclic phosphate, Fig. 1A right, 1C) have been shown to act as PKA-antagonists [17,34-36], whereas the Sp-cAMPS analogs and CAMP itself act as agonists (Fig. 1A left, 1B). The general assumption that Rp-cAMPS binds to the R-subunit in the intact PKA holoenzyme thus preventing complex dissociation [37] was addressed by a combination of SPR binding analysis and Mass spectrometry (BIA-MS).

Therefore the antagonist Rp-8-AHDAA-cAMPS (for chemical structure see Fig. 1C) and the agonist 8-AHA-cAMP were covalently coupled to two sensor surfaces on a single CM5 sensor chip. $250 \mathrm{nM}$ of each, PKA holoenzyme $\left(\mathrm{R}_{2} \mathrm{C}_{2}\right)$, free R-subunit and C-subunit were injected to both sensor surfaces. Fig. 6A shows the resulting binding curves for type I holoenzyme. Maximum binding signals of 17,000 and 6,900 RU on the antagonist and on the agonist surfaces were observed, respectively. These difference in the binding signals indicates that the entire holoenzyme complex is captured to the antagonist surface whereas on the agonist surface only the free R-subunit is bound, since the immobilised agonist causes holoenzyme dissociation and release of the $\mathrm{C}$-subunit. Hence, these differences in binding signals reflect the mass difference between the holoenzyme complex $\left(\mathrm{R}_{2} \mathrm{C}_{2}\right)$ and the free $\mathrm{R}$ subunit $\left(R_{2}\right)$. A control experiment was performed, injecting free R-subunit over both surfaces and similar binding signals of approximately 5,300 RU each were obtained for the agonist as well for the antagonist surface (Fig. 6A). Furthermore, binding signals to the agonist surface using free R-subunit and the PKA holoenzyme complex were in the same range, again indicating that the holoenzyme dissociates when interacting with the agonist surface. As an 
A

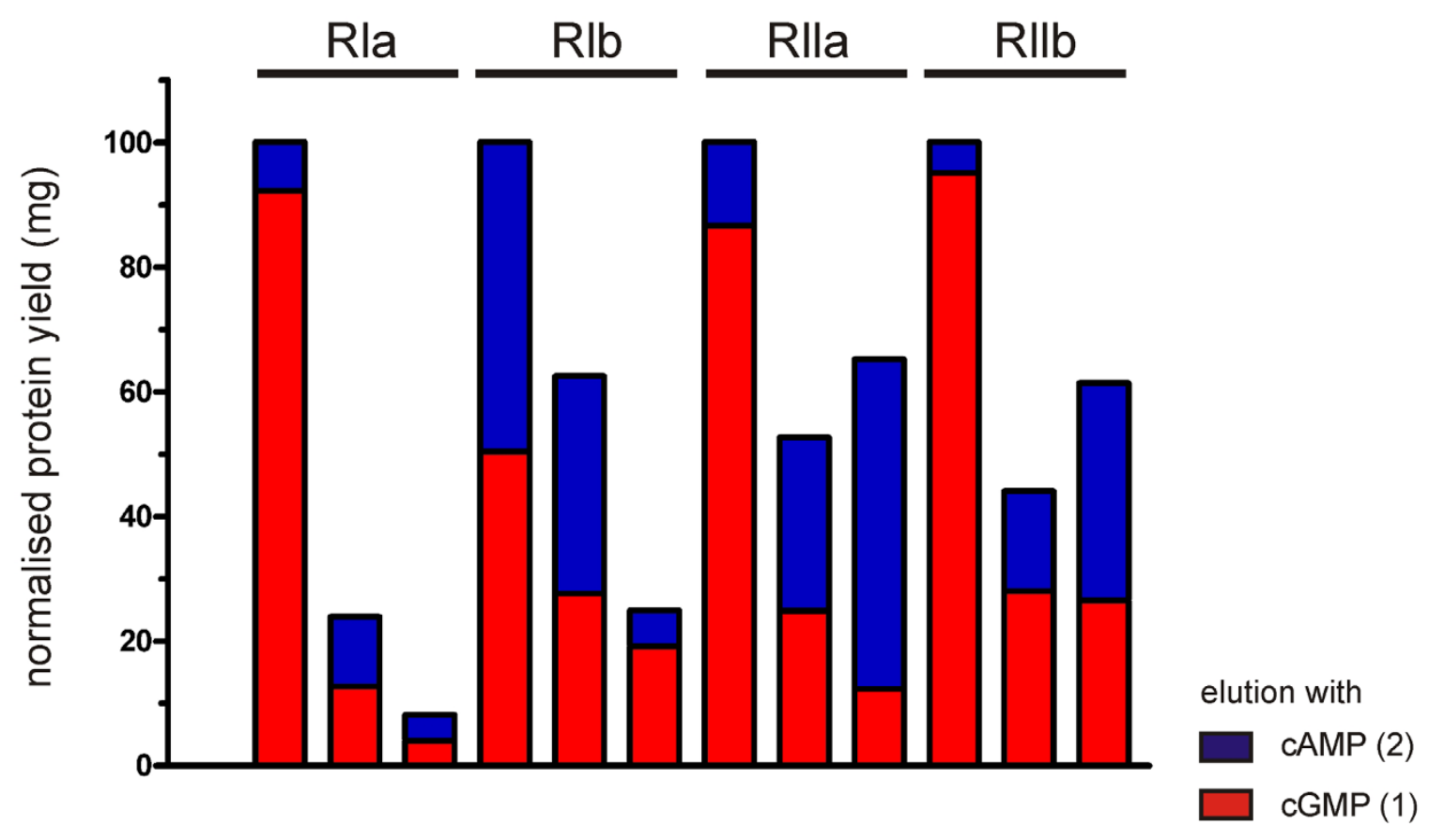

B

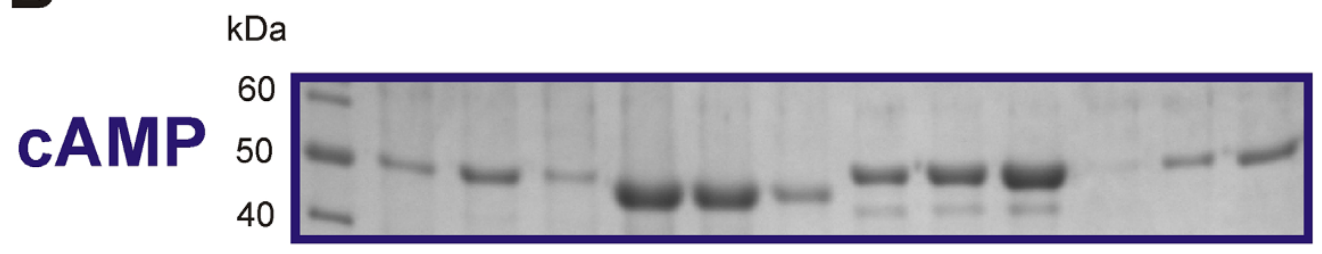

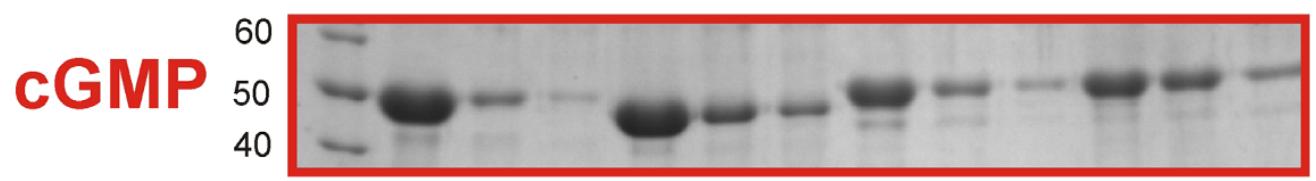

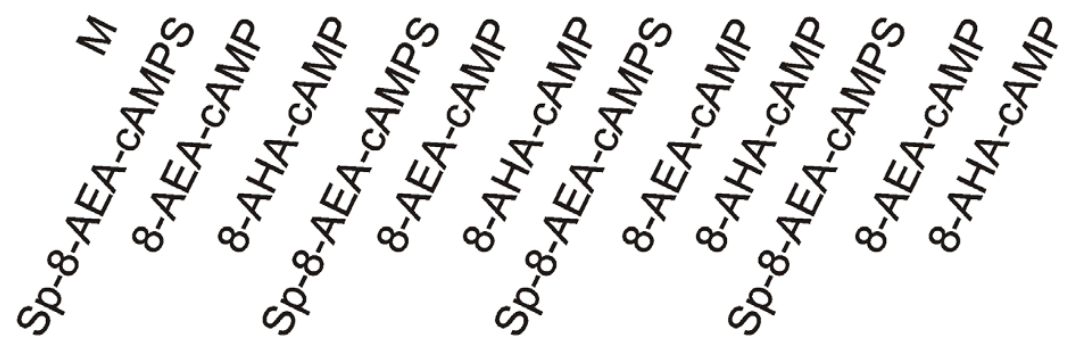

\section{Figure 5}

Improvements on CAMP analogs for the purification of all R-subunit isoforms. Comparison of the protein yield eluted from the agarose with cGMP (red bars) followed by CAMP (blue bars) indicated on the plot. Data were normalised to the total protein yield from both elution steps using Sp-8-AEA-cAMPS agarose as determined by BCA assay. The lower panel shows a SDS-PAGE of samples from each elution fraction (equal volumes of original fractions, cGMP elution red framed, cAMP elution blue framed). M: molecular weight marker (Page-Ruler Unstained Protein Ladder, Fermentas). 
A

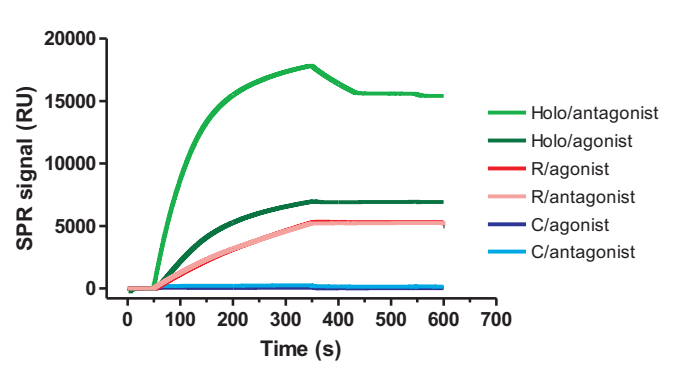

Holoenzyme

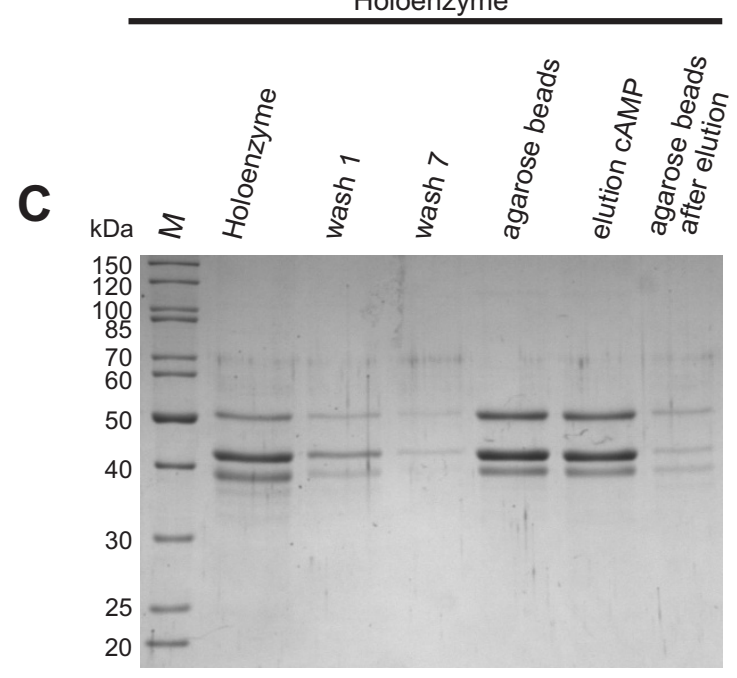

D

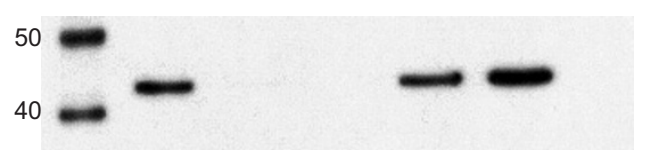

B

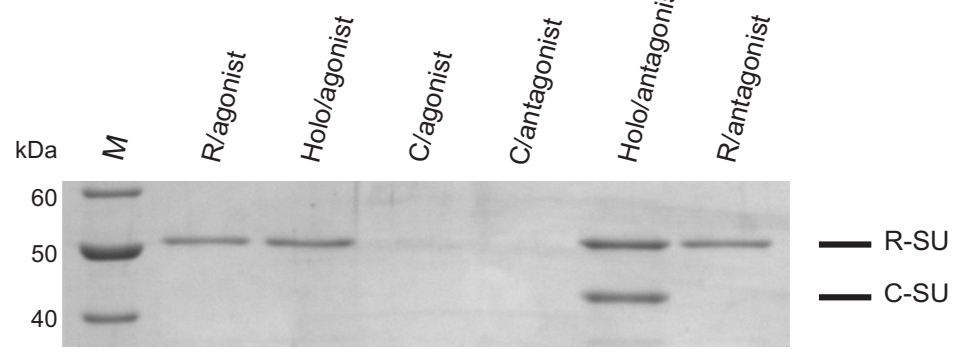

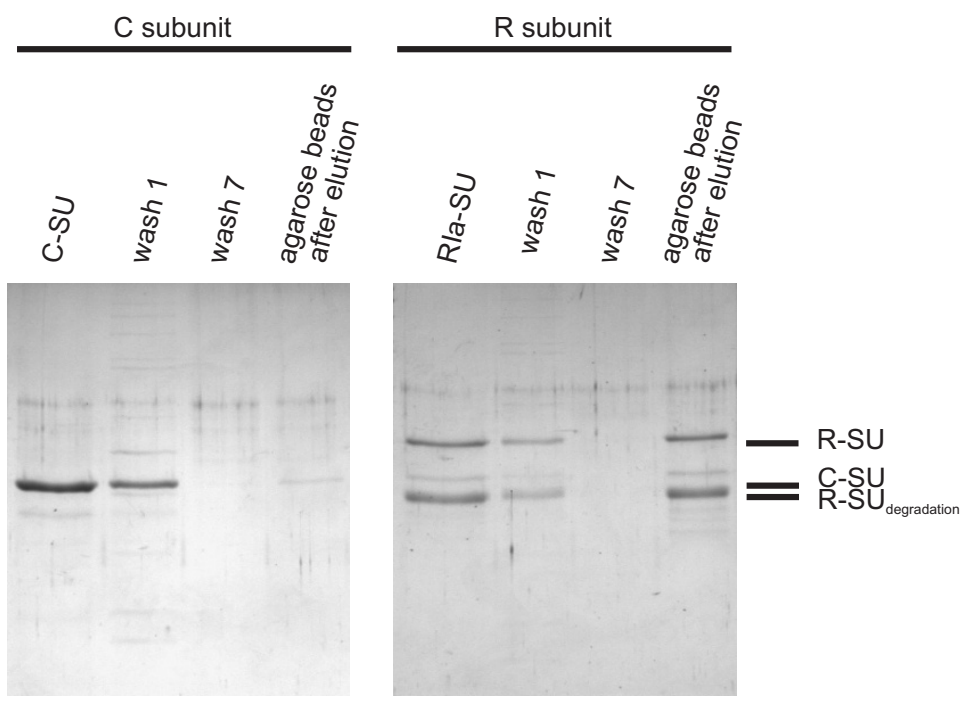

C-SU

\section{Figure 6}

Rp-cAMPS analogs bind the intact PKA holoenzyme complex. The entire PKA type I holoenzyme complex $\left(R_{2} C_{2}\right)$ binds highly specific to Rp-8-AHDAA-cAMPS as demonstrated by SPR (A), BIA MS (B) as well as affinity purification followed by SDS-PAGE (C) and Western blot analysis (D). (A) SPR binding pattern of type I holoenzyme, hRl $\alpha$ and $C \alpha$ (as indicated, 250 nM each) on antagonist (Rp-8-AHDAA-cAMPS) and agonist (8-AHA-cAMP) surfaces. Measurements were performed in buffer A containing $0.005 \% \mathrm{P} 20, \mathrm{I} \mathrm{mM}$ ATP and $10 \mathrm{mM} \mathrm{MgCl}$ at a flow rate of $5 \mu \mathrm{L} / \mathrm{min}$. (B) BIA-MS: SDS-PAGE analysis of protein recovered from the experiments depicted in (A). Type I holoenzyme, $\mathrm{R}$-subunit and $\mathrm{C}$-subunit were injected to the agonist and antagonist surfaces as described and were eluted with $0.2 \%$ SDS after a 4 min wash step. The eluted material from 15 repetitive runs was pooled and analysed by SDS-PAGE, MS and Western blot analysis (not shown). C-subunit (42 kDa) and R-subunit hRl $\alpha(50 \mathrm{kDa})$ are indicated. M: molecular weight marker (Page-Ruler, unstained protein ladder, Fermentas). (C) Binding of PKA type I holoenzyme complex $\left(\mathrm{R}_{2} \mathrm{C}_{2}\right.$, left panel), free $\mathrm{C}$-subunit (center panel) and free $\mathrm{R}$-subunit (right panel) to antagonist agarose (Rp-8-AHA-cAMPS, 600 pmoles, for chemical structure see Fig. IC) determined with SDS-PAGE. (D) Immunoblot analysis of SDS gels from panel (C) using anti-C-subunit antibody. 
additional control C-subunit alone was injected over both analog surfaces. No binding was observed, demonstrating that the C-subunit does not contribute to the binding signal.

To prove that the intact holoenzyme complex was bound to the antagonist sensor surface a BIA MS experiment was performed (Fig. 6A, B). $250 \mathrm{nM}$ of each, PKA holoenzyme $\left(\mathrm{R}_{2} \mathrm{C}_{2}\right)$, free R-subunit and C-subunit were injected and after a 4 min wash, the sensor surface was incubated with $0.2 \%$ SDS. Proteins bound to the nucleotide surface were eluted using the microrecovery function (Biacore 3000 Control Software 4.1) and the content of 15 subsequent elutions was subjected to SDS-PAGE (Fig. 6B), displaying two distinct bands. These bands correspond to R- and Csubunits, as identified by LC-ESI MS/MS and Western blot analysis (data not shown). Both, R- and C-subunit, were detected in equal amounts according to Coomassie staining (Fig. 6B), strongly supporting the hypothesis that functionally intact holoenzyme complex $\left(\mathrm{R}_{2} \mathrm{C}_{2}\right)$ was bound to the antagonist surface and subsequently eluted. For a control the same amount of holoenzyme was also injected to the agonist surface and analysed as described above. Only R-subunit, but no C-subunit, could be detected by SDS-PAGE (Fig. 6B), MS and Western blot analysis (data not shown).

Based on the BIA-MS results (Fig. 6B), the antagonist was coupled to agarose beads via NHS chemistry (Fig. 3). These beads were then incubated with purified holoenzyme complex. Samples of each step of the pull down experiment were analysed via a SDS-PAGE (Fig. 6C) as well as analysed by Western blot with an anti-C-subunit antibody (Fig. 6D), proving that Rp-cAMPS derivatised agarose provides an extremely valuable tool for holoenzyme purification. An additional control was performed with free R- and C-subunit. Both were incubated with the antagonist beads and then analysed with SDS-PAGE. Only the R-subunit but not C-subunit was detected verifying the BIA-MS results.

\section{Targeting the PKA interactome from pig brain using agonist and antagonist agaroses}

In a proof of principle experiment agonist (Sp-8-AEACAMPS) and antagonist agarose (Rp-8-AHDAA-cAMPS) were incubated with pig brain lysate in order to investigate, if endogenously expressed R-subunit and PKA holoenzyme can be pulled out of biological material. After incubation of the soluble protein fraction with the affinity resins, the beads were washed six times and the bound proteins were subsequently eluted with $20 \mathrm{mM}$ cAMP and analysed by SDS-PAGE (Fig. 7).

Using the agonist as affinity reagent, all four R-subunit isoforms were pulled from pig brain lysate. When using

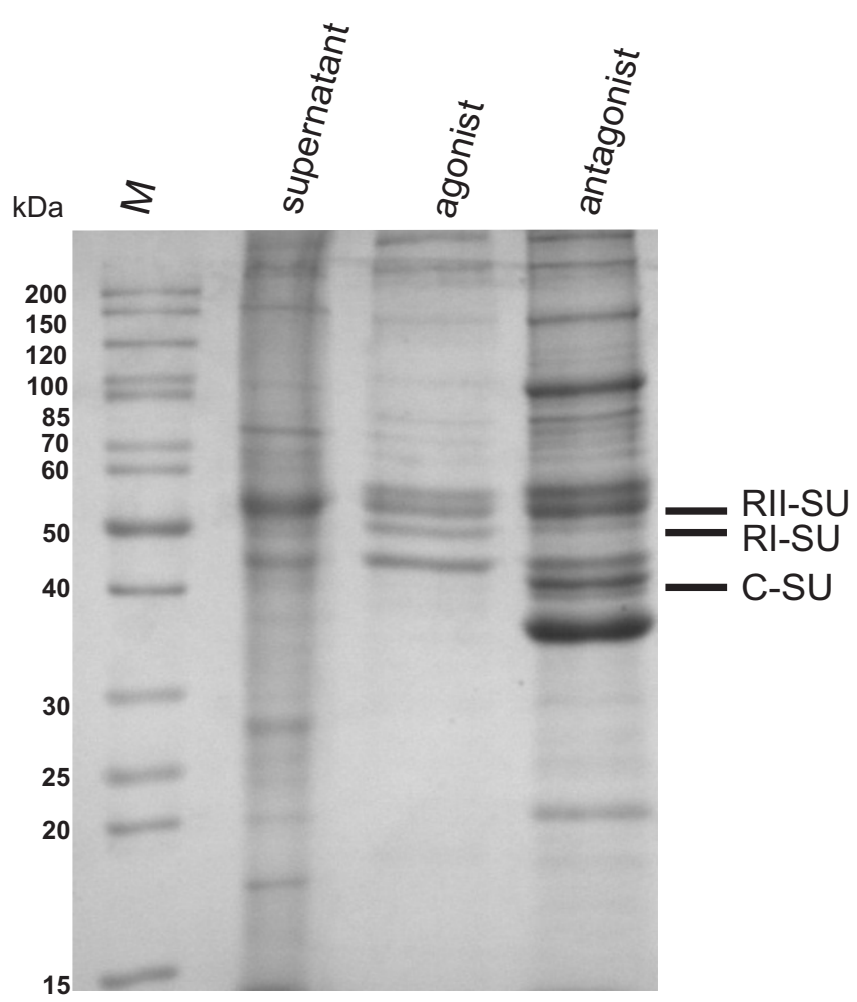

\section{Figure 7}

Affinity enrichment of components of the CAMPpathway using agonist and antagonist agaroses. Proteins from pig brain tissue were enriched using agonist (Sp-8AEA-cAMPS) and antagonist (Rp-8-AHDAA-cAMPS) agaroses and subsequently eluted with cAMP. Fractions were separated on a $12 \%$ SDS-PAGE. supernatant: soluble protein fraction of pig brain after lysis, filtration and centrifugation; agonist/antagonist: protein eluted from the agonist/antagonist agarose with $25 \mathrm{mM}$ cAMP. C-subunits (42 kDa), R-subunits $\mathrm{RI}(50 \mathrm{kDa})$ and RII $(52 \mathrm{kDa})$ subunits are indicated, each identified by MS (data not shown). M: molecular weight marker (Page-Ruler, unstained protein ladder, Fermentas).

the antagonist, additionally all major C-subunit isoforms $(\mathrm{C} \alpha, \mathrm{C} \beta$ and $\mathrm{C} \gamma$; Fig. 7) were identified based on MS (data not shown). In addition to the PKA subunits other distinct sets of proteins were pulled out from pig brain tissue using either agonist or antagonist agaroses (Bertinetti et al. in preparation). This indicates, that functional complexes of cAMP interactome can be pulled out of tissue lysates with these new chemical tools, proving the opportunity for the discovery of additional components of the cAMP signalling pathway.

\section{Discussion}

During the last 30 years several approaches have been used to selectively purify fully functional R-subunit isoforms of PKA, either endogenous from animal tissues [6] or recombinantly expressed in bacteria [38]. Most purifi- 
cation strategies have been based on ion exchange chromatography. There were also early attempts to use cAMP analogs linked via the $\mathrm{N} 6$ or $\mathrm{C} 8$ position of the adenine ring to an agarose matrix for affinity purification of R-subunits from several tissues [5]. In most cases, however, the affinity of the R-subunit to the various cAMP analogs used was too high to subsequently and successfully elute the protein efficiently. Only under harsh conditions could the R-subunit be removed from the matrix either by one of the two procedures: $7 \mathrm{M}$ urea $[6,39]$ or cAMP elution at elevated temperatures $[23,38]$; while still yielding not only less protein than using ion exchange chromatography but also protein that was insoluble and/or proteolytically degraded [26]. In order to increase the yield of nucleotidefree and highly active R-subunit attempts to use fusion tags for purification [40-42]. However, fusion tags to the $\mathrm{N}$-terminus as well as to the $\mathrm{C}$-terminus of the R-subunit turned out to be problematic. Modifications of the N-terminus can interfere with R-subunit dimerisation and binding of A kinase anchoring proteins [43]. Since fusion tags on the C-terminus are located in close proximity to the cAMP binding domains, the cyclic nucleotide binding properties can be affected. Cleavage of the tag is an additional purification step which may lead to a loss of protein as well as cause additional proteolytic products.

We synthesised 3 different Sp-cAMPS analogs (Sp-8-AEACAMPS, Sp-8-AHA-cAMPS, Sp-2-AHA-cAMPS) and characterised the binding to all four R-subunit isoforms in direct interactions studies using SPR. Subsequently these agonists were coupled to solid supports and used for affinity purification of recombinantly expressed R-subunits. All three analogs displayed superior purification strategies when compared to conventional cAMP analogs (8-AEACAMP, 8-AHA-CAMP).

Using Sp-8-AEA-cAMPS agarose it is now possible to obtain large yields of active and nucleotide-free R-subunit without the use of denaturants. This is especially important since remaining nucleotide in the $\mathrm{CNB}$ domain would interfere with subsequent studies. Furthermore decreased stability of Urea unfolded and refolded protein occurs [44].

In general, affinity reagents, addressing a specific subset of proteins or protein complexes, are of growing importance for many applications in proteomics. This includes enrichment of proteins or subcellular components as well as removal of unwanted cell debris subcellular components, proteins and metabolites. Therefore, our described CAMP analogs not only provide a highly selective tool as an affinity material for purification of PKA R-subunits, but can also serve as a tool that particularly targets the cAMP sub-proteome (Bertinetti $e t$ al. in preparation). Here we can demonstrate that components of cAMP signalling pathways were selectively complexed with their physiological interaction partners thus demonstrating that phosphorothioate cAMP analog agaroses are extremely valuable for comparable chemical proteomics studies. Furthermore, phosphorothioate cAMP analogs provide an additional advantage as they were shown to be highly stable against phosphodiesterase activity [45] and are therefore well suited for use with cellular lysates.

In a recent approach, Scholten et al. [24] used conventional cyclic nucleotide agaroses to pull out components of the CGMP/CAMP interactome from rat heart tissue in order to identify cyclic nucleotide binding proteins and their interaction partners. Since elution with cAMP from the 8-AEA-cAMP agarose was not sufficient for subsequent MS analysis, those studies had to be performed with material that was obtained by boiling the incubated agarose beads in SDS loading buffer. With the newly designed Spand Rp-cAMPS agaroses described here, specific binding and elution of CAMP binding proteins and a reduction of false positives can be achieved since elution with cAMP can be considered as an additional purification step. The use of these novel tools now enables us to also pull out interaction partners of intact holoenzyme, which is especially important for identification of novel interaction partners of the C-subunits of PKA such as the recently described A-kinase interacting proteins (AKIPs, [46]) in the holoenzyme form.

\section{Conclusion}

Novel cAMP analogs based on phosphorothioate were optimised in an iterative approach combining design, synthesis and direct SPR binding studies. After coupling to a solid support, two sets of chemical binders were tested for highly efficient purification procedure of all isoforms of PKA R-subunit. Sp-8-AEA-cAMPS was identified as the most valuable tool for purification purposes, yielding milligram amounts of both highly pure and active R-subunit within $8 \mathrm{~h}$. Furthermore, Sp- and Rp-cAMPS derived analogs have the potential to be employed in a chemical proteomics approach targeting distinct cAMP sub-proteomes.

\section{Methods \\ Chemicals}

All chemicals used were of the purest grade available and were obtained either from Sigma-Aldrich (Seelze), Roth (Karlsruhe) or Applichem (Darmstadt). The following CAMP-analogs were synthesised by Biolog LSI (Bremen): 8-AHA-CAMP， 8-AEA-CAMP， Sp-CAMPS， Sp-8-AHAcAMPS, Sp-2-AHA-cAMPS, Sp-8-AEA-cAMPS, Rp-cAMPS, Rp-8-AHA-cAMPS, Rp-8-AHDAA-cAMPS. A representative scheme with synthesis and coupling of Sp-8-AEA-cAMPS to agarose beads is provided in Fig. 3 . 


\section{Synthesis of cyclic nucleotide derivatives and coupling to agarose}

All cAMP- and $\omega$-aminoalkyl-substituted Sp-cAMPS analogs (for chemical structure see Fig. 1B) were synthesised as described $[22,47]$ with some minor modifications. Typically, $100 \mu$ moles of (Sp)-8-Br-cAMP(S), (Sp)-2-ClcAMP(S) or (Rp)-8-Br-cAMP(S) (Biolog) and 1,000 $\mu$ moles of $1, \omega$-diaminoalkan (Fluka) were dissolved in 10 $\mathrm{mL}$ water and refluxed until no starting material was detectable by HPLC analysis (first step in the reaction pathway Fig. 3). The reaction mixtures were neutralised with diluted $\mathrm{HCl}$, concentrated by rotary evaporation under reduced pressure, and subsequently purified by means of semi-preparative reversed phase HPLC (YMC ODS-A 120-11, YMC). The column was washed with 100 $\mathrm{mM} \mathrm{NaH} 2 \mathrm{PO}_{4}, \mathrm{pH} 7$, followed by water. Each cAMP(S) analog was eluted with a gradient from 100\% water to $100 \%$ acetonitrile. The product containing fractions were collected and evaporated under reduced pressure to obtain 8-AHA-cAMP, 8-AEA-cAMP, Sp-8-AHA-cAMPS, Sp8-AEA-cAMPS, Sp-2-AHA-cAMPS and Rp-8-AHDAACAMPS in yields of 60-80\% with purities > 99\% (by HPLC). The structure of each CAMP(S) analog was confirmed by UV/VIS spectrometry and FAB/MS or ESI/MS analysis.

CAMP(S) analogs were coupled to NHS-activated agarose beads (Affi-Gel ${ }^{\circledast} 10$, BIO-RAD) according to the manufacturer's instructions (Fig. 3). Briefly, 6.6 $\mu$ moles of cAMP(S) analog and $7.26 \mu$ moles ethyldiisopropylamine were added per mL settled gel, suspended in DMSO. Reaction mixture was carefully shaken for 2-18 h at ambient temperature until no further consumption of starting material was detectable by analytical HPLC monitoring. Any unreacted NHS-groups of the agarose gels were blocked by addition of $20 \mu$ moles ethanolamine per $\mathrm{mL}$ settled gel by incubation for $1 \mathrm{~h}$. After filtration and multiple washing with subsequently $2 \times 25 \mathrm{~mL} 20 \%$ ethanol, $2 \times 25 \mathrm{~mL} \mathrm{H}_{2} \mathrm{O}$ and $2 \times 25 \mathrm{~mL} 30 \mathrm{mM} \mathrm{NaH}_{2} \mathrm{PO}_{4}, \mathrm{pH} 7$, each agarose gel was stored in $30 \mathrm{mM} \mathrm{NaH}_{2} \mathrm{PO}_{4}, 1 \%$ $\mathrm{NaN}_{3}, \mathrm{pH} 7$ at $4{ }^{\circ} \mathrm{C}$. Ligand densities were $6 \mu$ moles $/ \mathrm{mL} 8$ AHA-cAMP, $6 \mu$ moles/mL 8-AEA-cAMP, $4 \mu$ moles $/ \mathrm{mL}$ Sp8-AEA-cAMPS agarose, $5 \mu$ moles/mL Sp-8-AHA-cAMPS agarose, $6 \mu$ moles/mL Sp-2-AHA-cAMPS agarose and 6 $\mu$ moles/mL Rp-8-AHDAA-cAMPS agarose.

\section{Direct binding studies of SP-cAMPS analogs using SPR}

Sp-2-AHA-cAMPS, Sp-8-AEA-cAMPS, Sp-8-AHA-cAMPS (for chemical structures see Fig. 1B), 8-AHA-cAMP and 8AEA-cAMP were dissolved in $100 \mathrm{mM}$ HEPES-KOH pH 8 by cautious heating $\left(\max .70^{\circ} \mathrm{C}\right)$ and filtered. The concentrations of the stock solutions were determined via their respective extinction coefficient. CM5 sensor chip surfaces (research grade, Biacore $\mathrm{AB}$ ) were activated for $10 \mathrm{~min}$ with NHS/EDC according to the manufacturer's instruc- tions (amine coupling kit, Biacore $\mathrm{AB}$ ). The analogs (3 $\mathrm{mM}$ ) were injected for $7 \mathrm{~min}$ (running buffer: $100 \mathrm{mM}$ HEPES, pH 8). Deactivation of the surface was performed with $1 \mathrm{M}$ ethanolamine- $\mathrm{HCl}, \mathrm{pH}$ 8.5. Each flow cell was activated, coupled and deactivated individually with a flow rate of $5 \mu \mathrm{L} / \mathrm{min}$ at $20^{\circ} \mathrm{C}$. A reference cell (Flow cell 1) was activated and deactivated without ligand immobilisation.

All interaction analyses were performed at $20^{\circ} \mathrm{C}$ in 150 $\mathrm{mM} \mathrm{NaCl}, 20 \mathrm{mM}$ MOPS, pH 7 (buffer A) containing $0.005 \%$ (v/v) surfactant P20, using a Biacore 2000 instrument (Biacore $\mathrm{AB}$ ). Binding analyses were performed by injection of $100 \mathrm{nM}$ hRI $\alpha$, hRI $\beta$, hRII $\alpha$ and $\mathrm{rRII} \beta$ (all proteins were purified classically by DEAE cellulose chromatography [48]) at a flow rate of $10 \mu \mathrm{L} / \mathrm{min}$. Association and dissociation were monitored for $5 \mathrm{~min}$ and $10 \mathrm{~min}$, respectively. Dissociation was performed in buffer A containing $0.005 \%$ P20 in the presence or absence of $3 \mathrm{mM}$ cGMP. The sensor surfaces were regenerated after each binding cycle by two short injections of $3 \mathrm{M}$ guanidinium $\mathrm{HCl}$. After subtracting the reference cell signal, binding data were normalised (Fig. 2).

\section{Purification of $h R I \alpha$ using Sp-cAMPS agaroses}

Bacterial cells overexpressing R-subunit were lysed using a French Pressure Cell (Thermo Electron) in lysis buffer containing $20 \mathrm{mM}$ MOPS pH 7, $100 \mathrm{mM} \mathrm{NaCl}, 1 \mathrm{mM} \beta$ mercaptoethanol, $2 \mathrm{mM}$ EDTA and $2 \mathrm{mM}$ EGTA (buffer A). The crude lysate was centrifuged at $27,000 \mathrm{~g}$ for $30 \mathrm{~min}$ at $4 \mathrm{C}$. Three different Sp-cAMPS agaroses (Sp-8-AHAcAMPS, Sp-8-AEA-cAMPS and Sp-2-AHA-cAMPS agarose) were tested side by side in a one step purification strategy. $1.2 \mu$ moles of coupled analog were used for each purification, corresponding to approximately $400 \mu \mathrm{L}$ of agarose slurry. $12 \mathrm{~mL}$ supernatant from $500 \mathrm{~mL}$ bacterial culture were incubated with the respective affinity matrices. Binding was carried out in a batch format by gently rotating over night at $4^{\circ} \mathrm{C}$. After washing the agarose seven times with $1.25 \mathrm{~mL}$ lysis buffer each, the protein was eluted with $1.25 \mathrm{~mL}$ of $10 \mathrm{mM}$ cGMP in buffer B (buffer A plus $1 \mathrm{mM}$ $\beta$-mercaptoethanol) by gentle rotation at $4^{\circ} \mathrm{C}$ for $1 \mathrm{~h}$ followed by an elution using $10 \mathrm{mM}$ cAMP in buffer $\mathrm{B}$ instead of cGMP. Excess of nucleotide was removed using a PD10 gel filtration column (Amersham Pharmacia). cGMP bound to the cyclic nucleotide binding pockets was removed by extensive dialysis against buffer $\mathrm{B}$.

The purification strategy of RI $\beta$ with Sp-8-AEA-cAMPS follows in principle the procedure described for RI $\alpha$.

\section{Purification of type II R-subunits using Sp-8-AEA-cAMPS agarose}

The purification strategy of RII isoforms follows the procedure described for hRI $\alpha$ except cell lysis was performed 
in buffer containing $20 \mathrm{mM}$ MES pH 6.5, $100 \mathrm{mM} \mathrm{NaCl}$, $5 \mathrm{mM}$ EDTA, $5 \mathrm{mM}$ EGTA and $5 \mathrm{mM} \beta$-mercaptoethanol (buffer $\mathrm{C}$ ) including the protease inhibitors Leupeptin (0,025 mg/100 mL, Biomol), TPCK and TLCK (each $1 \mathrm{mg} /$ $100 \mathrm{~mL}$, Biomol). After cell lysis, the soluble protein fraction was incubated in a batch format with Sp-8-AEAcAMPS agarose $(1.4 \mu \mathrm{mol}$ analog). The agarose was washed twice with $10 \mathrm{~mL}$ buffer D (20 mM MES pH 7, 1 $\mathrm{M} \mathrm{NaCl}, 5 \mathrm{mM} \beta$-mercaptoethanol) and subsequently with buffer $\mathrm{C}$ containing protease inhibitors. Two elution steps were performed with $1 \mathrm{~mL} 25 \mathrm{mM}$ cGMP in buffer C and exchanged to $20 \mathrm{mM}$ MES pH 6.5, $150 \mathrm{mM} \mathrm{NaCl}, 2$ mM EDTA, 2 mM EGTA and $1 \mathrm{mM} \beta$-mercaptoethanol using a PD10 column (Amersham).

\section{Compared purification of all R-subunits using different cAMP analog agaroses}

The side by side comparison of Sp-8-AEA-cAMPS, 8-AHACAMP and 8-AEA-cAMP for purification was performed as described for the RI and RII purification. Crude lysate from one litre expression culture was divided into three equal aliquots and incubated in a small scale experiment with $100 \mu \mathrm{L}$ of the respective agaroses. The cGMP elution was followed by a second elution step with 40 mM cAMP at room temperature for 30 minutes according to [18].

\section{BIA-MS}

Rp-8-AHDAA-cAMPS (for chemical structure see Fig. 1C) and 8-AHA-cAMP were dissolved by cautious heating (max. $60^{\circ} \mathrm{C}$ ) in $100 \mathrm{mM}$ Borate $\mathrm{pH} 8.5$ with $20 \%$ DMSO and $100 \mathrm{mM}$ HEPES pH 8, respectively, filtered and coupled to the sensor surface as described above. All microrecovery experiments were performed in buffer A containing $10 \mathrm{mM} \mathrm{MgCl} 2,1 \mathrm{mM}$ ATP with $0.005 \%$ (v/v) surfactant P20 on a Biacore 3000 instrument. 250 nM PKA type I holoenzyme $\left(\mathrm{R}_{2} \mathrm{C}_{2}\right)$, free $\mathrm{RI} \alpha$ subunit or C-subunit were injected over the analog sensor surfaces in separate experiments. The association phase was monitored for $5 \mathrm{~min}$ followed by a 4 min washing step with running buffer. Bound protein was eluted by incubating the sensor surface with $0.2 \%$ SDS for $90 \mathrm{~s}$ and the eluted material was recovered in a capped vial. The sensor surfaces were regenerated by three subsequent injections of $3 \mathrm{M}$ guanidinium $\mathrm{HCl}$.

The recovered material from 15 repetitive cycles was pooled and applied to a 12\% SDS-PAGE [49] (Fig. 6B) for protein identification via MS.

\section{Fishing of PKA holoenzyme complex with Rp-cAMPS agarose}

Purified recombinant $\mathrm{mC} \alpha$, hRI $\alpha$ and PKA holoenzyme were each incubated with Rp-8-AHDAA-cAMPS agarose (600 pmoles coupled analog, for chemical structure see Fig. 1C) for $2 \mathrm{~h}$ at $4^{\circ} \mathrm{C}$. The agarose was washed seven times with $1 \mathrm{~mL}$ buffer E (buffer B containing $1 \mathrm{mM}$ ATP and $10 \mathrm{mM} \mathrm{MgCl}_{2}$ ). Protein was eluted with $1 \mathrm{~mL} 20 \mathrm{mM}$ CAMP in buffer E by gentle rotation at room temperature for $1 \mathrm{~h}$. The entire supernatant of each step was precipitated with TCA and applied to SDS-PAGE (Fig. 6C). For Western blotting, the samples were transferred to PVDF membrane and immunoblotted with anti-PKA C-subunit antibody (Santa Cruz Biotechnology, PKA $\alpha$ cat C-20) visualised by enhanced chemiluminescence (Fig. 6D).

\section{Fishing of PKA holoenzyme complex with agonist and antagonist agarose from pig brain lysate}

Fresh pig brain tissue was homogenised in buffer F (buffer $\mathrm{E}$ in the presence of protease inhibitors (complete, EDTA free, Roche), $2 \mathrm{mM}$ NADH and $20 \mathrm{mM}$ sucrose). After centrifugation at $13,700 \mathrm{~g}$ for $25 \mathrm{~min}$, the supernatant was filtered and incubated with $150 \mu \mathrm{L}$ agarose (corresponding to $1 \mu$ mole of Sp-8-AEA-cAMPS or Rp-8-AHDAA-cAMPS) over night at $4{ }^{\circ} \mathrm{C}$. The beads were washed six times with $1.5 \mathrm{~mL}$ buffer F. Elution was carried out with $1 \mathrm{~mL}$ of buffer E containing $20 \mathrm{mM}$ cAMP by gentle rotation at room temperature for $1 \mathrm{~h}$. All samples were precipitated with TCA for SDS-PAGE (Fig. 7).

\section{Biochemical characterisation of the proteins}

The purification of the R-subunits was analysed by $12 \%$ SDS-PAGE [49] unless otherwise noted and proteins were stained with colloidal Coomassie Brilliant Blue dye modified after Neuhoff et al. [50-52]. After electrophoresis, remaining SDS was removed by heating and rinsing in distilled water. Overnight staining with $0.1 \%$ Coomassie $^{\circledast}$ Brilliant Blue G 250 in 5\% aluminium sulphate octadecahydrate and $2 \%$ phosphoric acid resulted in intense blue bands with low background (Fig. 4, 5, 6, 7). Protein concentration was determined by a colorimetric assay using BSA as a standard [53]. The biological activity of the proteins was verified by a spectrophotometric phosphotransferase assay using the substrate peptide Kemptide (LRRASLG, Biosynthan) according to Cook et al. [33].

\section{Mass spectrometry analysis}

Protein bands were excised from one-dimensional SDSPAGE [49] and digested in gel with trypsin according to published procedures [54], modified by omitting all prewashing steps. After equilibrating in water, the gel pieces (Fig. 4, 6B, 7) were excised and homogenised via centrifugation $(1,6000 \mathrm{~g})$ through $10 \mu \mathrm{L}$ pipet tips (MBP) and collected in small reaction vials (CS-Chromatographie Service). Destaining, reduction and alkylation were omitted and $25 \mu \mathrm{L}$ digestion buffer containing $50 \mathrm{mM}$ $\mathrm{NH}_{4} \mathrm{HCO}_{3}, 100 \mathrm{ng} / \mu \mathrm{L}$ of trypsin (sequencing grade, Promega) were added directly to the gel slurry and incubated at $50^{\circ} \mathrm{C}$ for a minimum $1 \mathrm{~h} \mathrm{[55].} \mathrm{After} \mathrm{a} \mathrm{short} \mathrm{cen-}$ trifugation the supernatants were diluted with $40 \mu \mathrm{L}$ of $0.3 \%$ formic acid for analysis in a nanoLC-ESI-MS/MS (nanoLC-Ultimate HPLC-system, LC Packings, Dionex 
coupled online to a linear ion trap mass spectrometer 4000 QTRAP $^{\mathrm{Tм}}$, Applied Biosystems), as described in $[56,57]$. The MS/MS spectra were searched against a nonredundant sequence database (MSDB) using MASCOT (Matrix Science), version 1.9.05. Taxonomy was restricted to mammals with variable modifications on deamidation (NQ), myristoylation (N-Term. G), oxidation (M) and phosphorylation (ST).

\section{Authors' contributions}

$\mathrm{DB}, \mathrm{SS}$ and SEH performed the expression and purification of the recombinant proteins as well as the biochemical characterisation and the chemical proteomics experiments. FS and HGG synthesised and purified the cyclic nucleotide analogs and performed coupling to the agarose. SD carried out the SPR measurements, OB the mass spectrometry analyses, SS the BIA-MS experiments and DB, SS and FWH wrote the manuscript and prepared the figures.

\section{Acknowledgements}

We thank Michaela Hansch, Marko Knoll, Antje Badel and Maike Vetter (Kassel University) for technical assistance as well as Undine Manzau and Ursula Havemann (Biolog LSI) for technical support. We thank Maria McGlone for carefully reading the manuscript. This work was supported by grants from the Deutsche Forschungsgemeinschaft (DFG, Hel818/4) to FWH and EU (LSHB-CT-2006-037189, thera-CAMP) to FWH, HGG, FS and SD. SS and SEH were supported by the Graduate Program of Kassel University. FWH's group is a member in the EU FP6 ProteomeBinders consortium.

\section{References}

I. Shabb JB: Physiological substrates of cAMP-dependent protein kinase. Chem Rev 200I, I0I(8):238I-24II.

2. Kim C, Vigil D, Anand G, Taylor SS: Structure and dynamics of PKA signaling proteins. Eur J Cell Biol 2006, 85(7):65I-654

3. Taylor SS, Kim C, Cheng CY, Brown SH, Wu J, Kannan N: Signaling through CAMP and CAMP-dependent protein kinase: diverse strategies for drug design. Biochim Biophys Acta 2008, 1784(I):16-26.

4. Rubin CS, Erlichman J, Rosen OM: Molecular forms and subunit composition of a cyclic adenosine 3',5'-monophosphatedependent protein kinase purified from bovine heart muscle. J Biol Chem 1972, 247(1):36-44.

5. Wilchek M, Salomon Y, Lowe M, Selinger Z: Conversion of protein kinase to a cyclic AMP independent form by affinity chromatography on N 6-caproyl 3',5'-cyclic adenosine monophosphate-sepharose. Biochem Biophys Res Commun 1971, 45(5): I I77-I I 84.

6. Ramseyer J, Kaslow HR, Gill GN: Purification of the cAMP receptor protein by affinity chromatography. Biochem Biophys Res Commun 1974, 59(2):8|3-82|.

7. Craven KB, Zagotta WN: CNG and HCN channels: two peas, one pod. Annu Rev Physiol 2006, 68:375-40I.

8. Omori K, Kotera J: Overview of PDEs and their regulation. Circ Res 2007, 100(3):309-327.

9. de Rooij J, Rehmann H, van Triest M, Cool RH, Wittinghofer A, Bos $\mathrm{JL}$ : Mechanism of regulation of the Epac family of cAMPdependent RapGEFs. J Biol Chem 2000, 275(27):20829-20836.

10. Berman HM, Ten Eyck LF, Goodsell DS, Haste NM, Kornev A, Taylor SS: The cAMP binding domain: an ancient signaling module. Proc Natl Acad Sci USA 2005, I 02(I):45-50.

II. Biskup C, Kusch J, Schulz E, Nache V, Schwede F, Lehmann F, Hagen $\mathrm{V}$, Benndorf $\mathrm{K}$ : Relating ligand binding to activation gating in CNGA2 channels. Nature 2007, 446(7134):440-443.
12. Schweinsberg S, Moll D, Burghardt NC, Hahnefeld C, Schwede F, Zimmermann B, Drewianka S, Werner L, Kleinjung F, Genieser HG, et al: Systematic interpretation of cyclic nucleotide binding studies using KinetXBase. Proteomics 2008, 8(6): | $2|2-| 220$.

13. Schwede F, Christensen A, Liauw S, Hippe T, Kopperud R, Jastorff B, Doskeland SO: 8-Substituted CAMP analogues reveal marked differences in adaptability, hydrogen bonding, and charge accommodation between homologous binding sites (Al/All and $\mathrm{BI} / \mathrm{BII}$ ) in CAMP kinase I and II. Biochemistry 2000, 39(30):8803-88I2.

14. Christensen AE, Selheim F, de Rooij J, Dremier S, Schwede F, Dao KK, Martinez A, Maenhaut C, Bos JL, Genieser HG, et al.: cAMP analog mapping of Epacl and CAMP kinase. Discriminating analogs demonstrate that Epac and CAMP kinase act synergistically to promote PC- $\mathbf{2}$ cell neurite extension. J Biol Chem 2003, 278(37):35394-35402.

15. de Wit RJ, Hoppe J, Stec WJ, Baraniak J, Jastorff B: Interaction of cAMP derivatives with the 'stable' cAMP-binding site in the cAMP-dependent protein kinase type I. Eur J Biochem 1982, I 22( I):95-99.

16. de Wit RJ, Hekstra D, Jastorff B, Stec WJ, Baraniak J, Van Driel R, Van Haastert PJ: Inhibitory action of certain cyclophosphate derivatives of CAMP on CAMP-dependent protein kinases. Eur J Biochem 1984, I 42(2):255-260.

17. Dostmann WR, Taylor SS, Genieser HG, Jastorff B, Døskeland SO, Ogreid D: Probing the cyclic nucleotide binding sites of cAMP-dependent protein kinases I and II with analogs of adenosine 3',5'-cyclic phosphorothioates. J Biol Chem 1990, 265(18): 10484-1049|.

18. Diller TC, Xuong NH, Taylor SS: Type II beta regulatory subunit of cAMP-dependent protein kinase: purification strategies to optimize crystallization. Protein Expr Purif 2000, 20(3):357-364.

19. Moll D, Schweinsberg S, Hammann C, Herberg FW: Comparative thermodynamic analysis of cyclic nucleotide binding to Protein Kinase A. Biol Chem 2007, 388(2): 163-172.

20. Corbin JD, Sugden PH, West L, Flockhart DA, Lincoln TM, McCarthy $D$ : Studies on the properties and mode of action of the purified regulatory subunit of bovine heart adenosine 3':5'monophosphate-dependent protein kinase. J Biol Chem 1978, 253(I I):3997-4003.

21. Dills WL Jr, Beavo JA, Bechtel PJ, Krebs EG: Purification of rabbit skeletal muscle protein kinase regulatory subunit using cyclic adenosine-3':5'-monophosphate affinity chromatography. Biochem Biophys Res Commun I 975, 62(I):70-77.

22. Dills WL Jr, Beavo JA, Bechtel PJ, Myers KR, Sakai LJ, Krebs EG: Binding of adenosine $3^{\prime}, 5^{\prime}$-'monophosphate dependent protein kinase regulatory subunit to immobilized cyclic nucleotide derivatives. Biochemistry 1976, I 5(I7):3724-373I.

23. Ramseyer J, Kanstein CB, Walton GM, Gill G: The use of affinity chromatography in purification of cyclic nucleotide receptor proteins. Biochim Biophys Acta 1976, 446(2):358-370.

24. Scholten A, Poh MK, van Veen TA, van Breukelen B, Vos MA, Heck A): Analysis of the cGMP/CAMP interactome using a chemical proteomics approach in mammalian heart tissue validates sphingosine kinase type I-interacting protein as a genuine and highly abundant AKAP. J Proteome Res 2006, 5(6): 1435 - I 447.

25. Scholten A, Visser NF, Heuvel RH van den, Heck A): Analysis of protein-protein interaction surfaces using a combination of efficient lysine acetylation and nanoLC-MALDI-MS/MS applied to the E9:Im9 bacteriotoxin - immunity protein complex. J Am Soc Mass Spectrom 2006, I7(7):983-994.

26. Potter RL, Stafford PH, Taylor S: Regulatory subunit of cyclic AMP-dependent protein kinase I from porcine skeletal muscle: purification and proteolysis. Arch Biochem Biophys 1978, 190(I): $174-180$.

27. Vigil D, Lin JH, Sotriffer CA, Pennypacker JK, McCammon JA, Taylor SS: A simple electrostatic switch important in the activation of type I protein kinase A by cyclic AMP. Protein Sci 2006, I5:I|3-121.

28. Vigil D, Blumenthal DK, Heller WT, Brown S, Canaves JM, Taylor SS, Trewhella J: Conformational differences among solution structures of the type Ialpha, Ilalpha and Ilbeta protein kinase A regulatory subunit homodimers: role of the linker regions. J Mol Biol 2004, 337(5): I I83-I I 94. 
29. Stokka AJ, Gesellchen F, Carlson CR, Scott JD, Herberg FW, Tasken $\mathrm{K}$ : Characterization of A-kinase-anchoring disruptors using a solution-based assay. Biochem J 2006, 400(3):493-499.

30. Hall DR, Cann JR, Winzor DJ: Demonstration of an upper limit to the range of association rate constants amenable to study by biosensor technology based on surface plasmon resonance. Anal Biochem 1996, 235(2): 175-184.

31. Schuck P, Minton AP: Analysis of mass transport-limited binding kinetics in evanescent wave biosensors. Anal Biochem 1996, 240(2):262-272

32. Herberg FW, Zimmermann B: Analysis of protein kinase interactions using biomolecular interaction analysis. In Protein Phosphorylation - A Practical Approach Second edition. Edited by: Hardie DG. Oxford University Press; 1999:335-371.

33. Cook PF, Neville ME Jr, Vrana KE, Hartl FT, Roskoski R Jr: Adenosine cyclic 3',5'-monophosphate dependent protein kinase: kinetic mechanism for the bovine skeletal muscle catalytic subunit. Biochemistry 1982, 2 I(23):5794-5799.

34. Van Haastert PJ, Van Driel R, Jastorff B, Baraniak J, Stec WJ, De Wit RJ: Competitive CAMP antagonists for cAMP-receptor proteins. J Biol Chem 1984, 259( I 6): 10020-10024.

35. Dostmann WR, Taylor SS: Identifying the molecular switches that determine whether (Rp)-cAMPS functions as an antagonist or an agonist in the activation of CAMP-dependent protein kinase I. Biochemistry 199I, 30(35):87|0-87|6.

36. Dostmann WR: (RP)-cAMPS inhibits the cAMP-dependent protein kinase by blocking the CAMP-induced conformational transition. FEBS Lett 1995, 375(3):23I-234.

37. Das R, Melacini G: A Model for Agonism and Antagonism in an Ancient and Ubiquitous cAMP-binding Domain. J Biol Chem 2007, 282(I):58I-593.

38. Saraswat LD, Filutowicz M, Taylor SS: Expression of the type I regulatory subunit of CAMP-dependent protein kinase in Escherichia coli. | Biol Chem 1986, 26 I(24): I 109|-II096.

39. Builder SE, Beavo JA, Krebs EG: Stoichiometry of CAMP and I,N6-etheno-cAMP binding to protein kinase. I Biol Chem 1980, 255(6):2350-2354

40. Kopperud R, Christensen AE, Kjarland E, Viste K, Kleivdal H, Doskeland SO: Formation of inactive CAMP-saturated holoenzyme of CAMP-dependent protein kinase under physiological conditions. J Biol Chem 2002, 277( I 6): I3443-13448.

4I. Dao KK, Teigen K, Kopperud R, Hodneland E, Schwede F, Christensen AE, Martinez A, Doskeland SO: EpacI and cAMP-dependent Protein Kinase Holoenzyme Have Similar cAMP Affinity, but Their CAMP Domains Have Distinct Structural Features and Cyclic Nucleotide Recognition. J Biol Chem 2006, 28I(30):2I500-2I5II.

42. Solberg R, Tasken K, Wen W, Coghlan VM, Meinkoth JL, Scott JD, Jahnsen T, Taylor SS: Human regulatory subunit RI beta of cAMP-dependent protein kinases: expression, holoenzyme formation and microinjection into living cells. Exp Cell Res 1994, 2 I 4(2):595-605.

43. Herberg FW, Maleszka A, Eide T, Vossebein L, Tasken K: Analysis of A-kinase anchoring protein (AKAP) interaction with protein kinase A (PKA) regulatory subunits: PKA isoform specificity in AKAP binding. I Mol Biol 2000, 298(2):329-339.

44. Canaves JM, Leon DA, Taylor SS: Consequences of cAMP-binding site mutations on the structural stability of the type I regulatory subunit of CAMP-dependent protein kinase. Biochemistry 2000, 39(49): |5022-|1503|

45. Schaap P, van Ments-Cohen M, Soede RD, Brandt R, Firtel RA, Dostmann W, Genieser HG, Jastorff B, van Haastert PJ: Cell-permeable non-hydrolyzable cAMP derivatives as tools for analysis of signaling pathways controlling gene regulation in Dictyostelium. J Biol Chem 1993, 268(9):6323-6331.

46. Sastri M, Barraclough DM, Carmichael PT, Taylor SS: A-kinaseinteracting protein localizes protein kinase $A$ in the nucleus. Proc Natl Acad Sci USA 2005, 102(2):349-354.

47. Long RA, Robins RK, Townsend LB: Purine nucleosides. XV. The synthesis of 8-amino and 8-substituted aminopurine nucleosides. J Org Chem 1967, 32(9):275I-2756.

48. Corbin JD, Keely SL, Park CR: The distribution and dissociation of cyclic adenosine 3':5'-monophosphate-dependent protein kinases in adipose, cardiac, and other tissues. J Biol Chem 1975, 250(I):218-225
49. Laemmli UK: Cleavage of structural proteins during the assembly of the head of bacteriophage T4. Nature 1970, 227(5259):680-685.

50. Neuhoff $\mathrm{V}$, Stamm R, Eibl H: Clear background and highly sensitive protein staining with Coomassie Blue dyes in polyacrylamide gels: A systematic analysis. Electrophoresis 1985, 6(9):427-448.

5I. Neuhoff $\mathrm{V}$, Arold N, Taube D, Ehrhardt W: Improved staining of proteins in polyacrylamide gels including isoelectric focusing gels with clear background at nanogram sensitivity using Coomassie Brilliant Blue G-250 and R-250. Electrophoresis 1988, 9(6):255-262.

52. Kang DH, Gho YS, Suh MK, Kang CH: Highly sensitive and fast protein detection with coomassie brilliant blue in sodium dodecyl sulfate-polyacrylamide gel electrophoresis. Bull Korean Chem Soc 2002, 23(I I): 15 II-15। 2 .

53. Bradford MM: A rapid and sensitive method for the quantitation of microgram quantities of protein utilizing the principle of protein-dye binding. Anal Biochem 1976, 72:248-254.

54. Rosenfeld J, Capdevielle J, Guillemot JC, Ferrara P: In-gel digestion of proteins for internal sequence analysis after one- or twodimensional gel electrophoresis. Anal Biochem 1992, 203(I): 173-179.

55. Finehout EJ, Cantor JR, Lee KH: Kinetic characterization of sequencing grade modified trypsin. Proteomics 2005, 5(9):23|9-232|.

56. Gesellchen F, Bertinetti O, Herberg FW: Analysis of posttranslational modifications exemplified using protein kinase A. Biochim Biophys Acta 2006, I 764(1 2): | 788-1800.

57. Schaefer H, Chamrad DC, Marcus K, Reidegeld KA, Bluggel M, Meyer HE: Tryptic transpeptidation products observed in proteome analysis by liquid chromatography-tandem mass spectrometry. Proteomics 2005, 5(4):846-852.

58. Humphrey W, Dalke A, Schulten K: VMD: visual molecular dynamics. J Mol Graph 1996, I4(I):27-28.
Publish with Bio Med Central and every scientist can read your work free of charge

"BioMed Central will be the most significant development for disseminating the results of biomedical research in our lifetime. "

Sir Paul Nurse, Cancer Research UK

Your research papers will be:

- available free of charge to the entire biomedical community

- peer reviewed and published immediately upon acceptance

- cited in PubMed and archived on PubMed Central

- yours - you keep the copyright
BiolMedcentral 